ROCZNIKI TEOLOGICZNE

Tom LXVIII, zeszyt $10-2021$

DOI: https://doi.org/10.18290/rt.216810.6

URSZULA DUDZIAK

\title{
PRZYCZYNY SUKCESU W POLSKIEJ PROFILAKTYCE PALENIA TYTONIU
}

\author{
SUCCESS FACTORS \\ IN THE PREVENTION OF TOBACCO SMOKING IN POLAND
}

\begin{abstract}
A b s t r a c t. The significant decrease in the number of cigarettes sold in Poland, of smokers in general and of lung cancer cases among men aged 35 to 54 demands an in depth study of how that was achieved. The purpose of analyses undertaken in this article is to identify the reasons for that success and to present Polish testimony on that subject to the audience both at home and abroad. It is worth doing in order to: - record the timeline of achieved results, - appreciate key figures behind this success, - acquire their followers, - show a valuable example to continuators of pro-health activities. Materials gathered in this work were obtained from "prof. Franciszek Venulet" conferences on prevention of tobacco smoking, various publications devoted to this subject as well as first-hand knowledge of specific activities undertaken or inspired by prof. dr hab. Witold Zatoński, by Fr. prof. dr hab. Czesław Cekiera and by their colleagues from Maria Skłodowska-Curie Institute of Oncology in Warsaw, from the "Health Promotion" Foundation and from the Department of Social Psychoprophylaxis at John Paul II Catholic University of Lublin.
\end{abstract}

Keywords: smoking; prevention; success in Poland.

\section{WSTĘP}

Przykazanie „Nie będziesz zabijał” (Wj 20,13; Pwt 5,17) dotyczy nie tylko zakazu bezpośredniego czynu uśmiercenia człowieka, ale także ochrony zdrowia poprzez eliminowanie czynników szkodliwych. Skłania przy tym do

Dr hab. URSZULA DUDZIAK, prof. KUL - Katedra Nauk o Rodzinie, Katolicki Uniwersytet Lubelski Jana Pawła II, Al. Racławickie 14, Lublin 20-950; e-mail: urszula.dudziak@kul.pl; ORCID: https://orcid.org/0000-0001-5144-7708. 
uwzględnienia zarówno troski o innych, jak i rezygnacji z używania toksycznych substancji przez samego siebie. Indywidualna i społeczna świadomość szkodliwości narkotyków, alkoholu czy palenia papierosów nie ma bezpośredniego przełożenia na dystans wobec nich. Do niektórych nałogów, z racji ich powszechności, społeczeństwo się przyzwyczaiło. W następstwie tego wiele osób przyjęło niebezpieczną postawę tolerancji prowadzącą do zwalniania się z jakiegokolwiek oporu, napominania i przeciwdziałania temu, co krzywdzi konkretnego człowieka i otaczających go ludzi, do bierności i rezygnacji z zapobiegania działaniom szkodliwym. Wypaczeniem zasad autentycznej profilaktyki jest także próba zmniejszania negatywnych następstw szkodliwych działań, zamiast przeciwdziałania niewłaściwym zachowaniom prowadzącym do uzależnienia ${ }^{1}$. Taki brak reakcji dotyczył zwłaszcza najczęstszego z nałogów, jakim jest palenie tytoniu. Nałóg ten, prawdopodobnie przez powszechność występowania i zbyt małą znajomość negatywnych skutków, był pobłażany, jego szkodliwość bagatelizowana, a pojawiające się czasem zakazy palenia nagminnie łamane. Wystarczy wskazać na absurdalność stawianych w towarzystwie pytań typu: „czy mogę zapalić?". Bardziej jednoznaczna drastyczna, ale prawdziwa forma stawianych kwestii: „,zy mogę zaszkodzić Państwa zdrowiu?”, „albo czy mogę narazić kogoś z Was na raka płuc?" w ogóle nie miałaby miejsca, albo natychmiast uzyskałaby negatywną odpowiedź.

\footnotetext{
${ }^{1}$ Przykładem tego jest wręczanie strzykawek jednorazowego użytku i sterylnych igieł narkomanom, rozdawanie prezerwatyw przygodnie współżyjącym i prostytuującym się osobom, przepisywanie uzależnionym metadonu, tworzenie pokoi konsumpcyjnych i injekcyjnych, drug consumption room: „są to miejsca, w których osoba używająca narkotyków (głównie dożylnie, choć nie tylko) może w sterylnych warunkach i pod opieką i nadzorem wykwalifikowanego personelu, przyjąć przyniesione przez siebie narkotyki”. Bartosz Michalewski, Centrum drop in $w$ Krakowie. Ograniczanie szkód zdrowotnych i praca z użytkownikami narkotyków w dobie pandemii COVID-19, Opublikowano: 28 stycznia 2021, https://www.narkomania.org.pl/czytel nia/ograniczanie-szkod-zdrowotnych-i-praca-z-uzytkownikami-narkotykow-w-dobie-pandemiicovid-19/, dostęp 04.06.2021; Podobne działanie jest wtedy, gdy zamiast całkowitego zerwania z nałogiem, z ewentualnym, czasowym, zażywaniem leku hamującego ośrodek głodu i przyjemności, postuluje się inny rodzaj podania czynnika uzależniającego i szerzenie reklamy plastrów bądź gum z nikotyną dla palaczy. Iga Hintz, Jak rzucić palenie? Jak działaja plastry, gumy, spraye, pastylki na rzucanie palenia? 31 maja 2019, https://apteline.pl/artykuly/jak-rzucicpalenie-jak-dzialaja-plastry-gumy-spraye-pastylki-na-rzucenia-palenia[dostęp04.06.2021].Takimi zamiennikami, dla niektórych palaczy, są również e-papierosy. Peter Hajek, Anna PhillipsWaller, Dunja Przulj, Francesca Pesola, Katie Myers Smith, Natalie Bisal, Jinshuo Li,Steve Parrott, Peter Sasieni, Lynne Dawkins, Louise Ross, Maciej Goniewicz, i in. „A Randomized Trial of E-Cigarettes versus Nicotine-Replacement Therapy”, New England Journal of Medicine 380(2019): 629-637; DOI: 10.1056/NEJMoa1808779 (dostęp 04.06.2021).
} 
Podejmowanie tematu palenia tytoniu ma szczególne znaczenie zarówno z powodu wysokiej liczby palaczy (nadal ponad miliard ludzi na świecie i $26 \%$ mieszkających w Polsce) $)^{2}$, jak i wielu negatywnych: fizycznych, psychicznych, duchowych i społecznych skutków tego uzależnienia ${ }^{3}$. Szczególną wartość ma zapobieganie sięganiu po papieros, ponieważ wiele chorób odtytoniowych prowadzi do śmierci. Rak płuc i inne nowotwory oraz pozostałe choroby, typowe dla palaczy, odpowiadają za „, $8 \mathrm{mln}$ zgonów na świecie rocznie, z tego $7 \mathrm{mln}$ związanych z czynnym paleniem, a 1,2 mln - z biernym paleniem"4. Oprócz terapii konieczna jest więc promocja zdrowia, prewencja i profilaktyka.

Charakterystyczną cechą zadań profilaktycznych jest nieodzowna stałość ich oddziaływań, konieczność dużego zasięgu obejmująca ludzi w różnym wieku, różnorodność form przekazu kierowanego do wszystkich grup społecznych. Podobnie, jak odporność społeczną w przypadku epidemii można uzyskać wówczas, gdy całe społeczeństwo jest zaangażowane w jej zwalczanie, tak i epidemia palenia tytoniu wymaga właściwych postaw wszystkich ludzi. Wiedział o tym, zainspirowany badaniami wpływu palenia tytoniu, prowadzonymi przez prof. Franciszka Venuleta $(1878-1967)^{5}$, światowej sławy epidemiolog prof. Witold Zatoński. Wiele lat swojego życia poświęcił on trosce o zdrowie publiczne, promocję zdrowia i wielorakie sposoby zapobiegania działaniom chorobotwórczym, takim jak palenie tytoniu. Problem palenia tytoniu nie był obojętny również założycielowi pierwszej w Polsce Katedry Psychoprofilaktyki Społecznej w Instytucie Psychologii Katolickiego Uniwersytetu Lubelskiego w 1987 roku, Ks. prof. Czesławowi Cekierze, który swą wiedzą teologiczną i psychologiczną chętnie dzielił się z lekarzami i innymi specjalistami angażującymi się w przeciwdziałanie ryzyku uzależnień ${ }^{6}$.

2 Centrum Badania Opinii Społecznej, Palenie papierosów, Komunikat z badań, Nr 104/ 2019: 2, https://cbos.pl/SPISKOM.POL/2019/K_104_19.PDF (dostęp 07.07.2021).

${ }^{3}$ Urszula Dudziak, „Dziecko zagrożone dymem tytoniowym”, w Międzynarodowy Kongres „O godność dziecka. Warszawa 18-20 maja 2001, red. Ewa Kowalewska, Małgorzata Wyszyńska, 129-139 (Gdańsk: Klub Przyjaciół Ludzkiego Życia, 2001); Czesław Cekiera, Witold Zatoński (red.), Palenie tytoniu wolność czy zniewolenie? (Lublin: Towarzystwo Naukowe KUL, 2001).

4 Zbigniew Wojtasiński, WHO: liczba palacych papierosy meżczyzn przestaje rosnać i zacznie spadać (20.12.2019). Ministerstwo Edukacji Narodowej, Nauka w Polsce, https:// naukawpolsce.pap.pl/aktualnosci/news $\% 2 \mathrm{C} 80018 \% 2 \mathrm{Cwho-liczba-palacych-papierosy-mezczyzn-}$ przestaje-rosnac-i-zacznie-spadac (dostęp 07.07.2021).

${ }^{5}$ Franciszek Venulet, Co o natogu palenia tytoniu wiedzieć należy (Warszawa: „Wiedza Powszechna", 1956). Ta pionierska w tej dziedzinie książka miała 6 wydań, opublikowanych w latach 1956-1958 w języku polskim przechowywanych przez 8 bibliotek członkowskich WorldCat na całym świecie.

${ }^{6}$ Jego pierwsze i fundamentalne dla psychoprofilaktyki książki to: Czesław Cekiera, 
Trud pracy profilaktyków niejednokrotnie pomnaża brak oczekiwanych rezultatów na szeroką skalę. Podobnie, zaangażowanie w pomoc konkretnej osobie może kończyć się frustracją i zniechęceniem, gdy u uzależnionego przerwany zostaje czas abstynencji i następuje kolejny powrót do nałogu. Wzmocnieniem postaw psychoprofilaktycznych jest informowanie o sukcesach, a takie - po latach pracy wielu osób, przede wszystkim: lekarzy, pielęgniarek, psychologów, socjologów, nauczycieli, doradców życia rodzinnego, duszpasterzy, dziennikarzy, polityków, działaczy samorządowych - udało się odnotować w zapobieganiu palenia tytoniu. Świadczy o tym zmniejszający się odsetek palaczy tytoniu. Z danych Centrum Badania Opinii Społecznej wynika, że od lutego 1997 roku do lipca 2019 roku grupa palących tytoń Polaków zmniejszyła się o 11 punktów procentowych $(37 \%-26 \%)^{7}$. Tak pozytywne rezultaty są owocem pracy konkretnych ludzi. Celem artykułu jest przedstawienie ich i wskazanie jako przykładu kolejnym pokoleniom, a także scharakteryzowanie przyjętego przez nich podejścia do profilaktyki, stosowanych form i uzyskanych rezultatów, aby znalazły naśladowców.

\section{OSOBOWOŚĆ ZAANGAŻOWANA, WIEDZA I PASJA}

Działania społeczne, podejmowane przez ludzi i dla ludzi, wymagają właściwej organizacji, umiejętnej współpracy i odpowiedzialnego przywództwa. Charyzmatyczna osobowość pociaga wielu, udziela swoich pasji, motywuje i mobilizuje do podobnej twórczości i współdziałania. Wielkie dzieła, zarówno w Polsce, jak i w innych krajach, mogły się dokonać dzięki istnieniu liderów ${ }^{8}$. Ich zadaniem było prowadzić współpracowników po wytyczonych drogach wiodących do zamierzonego celu i nie cofać się, mimo trudności i przeciwności. Dobry

Etiologia i motywacja usiłowanych samobójstw. Studium psychologiczne (Warszawa, Akademia Teologii Katolickiej, 1975); Tenże, Toksykomania: narkomania, lekomania, alkoholizm, nikotynizm (Warszawa: Państwowe Wydawnictwo Naukowe, 1985); Tenże, Psychoprofilaktyka uzależnień oraz terapia i resocjalizacja osób uzależnionych. Metody, programy, modele, zakłady, wspólnoty (Lublin: Towarzystwo Naukowe KUL, 1992); Tenże, Ryzyko uzależnień (Lublin: Towarzystwo Naukowe KUL, 1994). Tenże, W obronie życia i zdrowia (Białystok: Wydawnictwo Niepaństwowej Wyższej Szkoły Pedagogicznej, 2011). Kolejne, dotyczące profilaktyki palenia tytoniu, przedstawione zostaną w dalszej części artykułu.

7 Centrum Badania Opinii Społecznej, Palenie papierosów. Komunikat z badań, Nr 104/ 2019: 2, https://cbos.pl/SPISKOM.POL/2019/K_104_19.PDF (dostęp 07.07.2021).

${ }^{8}$ Przykładowo: Karol Wojtyła - Jan Paweł II, Matka Teresa z Kalkuty, Ks. Prof. dr hab. Franciszek Blachnicki. 
przywódca to człowiek mądry i odpowiedzialny, troszczący się o innych i doceniający tych, którzy dokładają swoje, choćby najmniejsze „cegiełki” do zaplanowanej przez niego budowli. Promotorami troski o zdrowie Polaków, a także autorytetami dla tych, którzy zabiegają o kondycję zdrowotna polskiego społeczeństwa, są; Prof. dr hab. Witold Zatoński i Ks. Prof. dr hab. Czesław Cekiera. Dzięki osobistemu doświadczeniu wieloletniej znajomości i współpracy mogę z przekonaniem i uznaniem przekazać informacje o tym, w czym dane mi było uczestniczyć, jakie treści słyszeć, jakie działania podziwiać.

Szczególnymi i bardzo cennymi cechami charakteru ludzi prawdziwie mądrych, wykształconych, znanych w szerokim świecie i piastujących wysokie stanowiska, są pokora, bezpośredniość i otwartość na drugiego człowieka. Te właśnie cechy były i są widoczne od wielu lat u ponad dziewięćdziesięcioletniego Ks. Prof. Cekiery. Życzliwość, łatwość nawiązywania kontaktu, przyjacielskie relacje, gotowość dzielenia się wiedzą i doświadczeniem stanowią podstawę dobrej współpracy. Bardzo pozytywne, personalne podejście i serdeczny sposób traktowania widoczne były w odniesieniach Ks. Prof. Cekiery do osób, z którymi podejmował współdziałania: naukowe, badawcze, dydaktyczne, organizacyjne, duszpasterskie, doradcze czy terapeutyczne. Ksiądz Profesor słynął z licznych znajomości w Polsce i za granicą. Jego notes był wypełniony adresami i numerami telefonów, które skrzętnie przepisywał i uzupełniał. Oprócz licznych kontaktów z zagranicznymi specjalistami, gromadzenia testów i kwestionariuszy, podejmowania badań naukowych, organizowania konferencji, publikowania książek i artykułów, wygłaszania wykładów, prowadzenia prac magisterskich i doktorskich, zajmował się psychoprofilaktyką w kontaktach indywidualnych i w wspieraniu działań społecznych. Sprzyjał pomysłom tworzenia: ośrodków dla osób uzależnionych, świetlic terapeutycznych i wszelkich innych form pomocy dla potrzebujących. Zachęcał, mobilizował, gratulował, chwalił, radził, komentował, pytał, słuchał, odpowiadał, wskazywał właściwą drogę. Będąc profesorem psychologii nie poprzestał na dociekaniach teoretycznych, ale również podejmował działania praktyczne pomagając pacjentom swym doradztwem, poradnictwem, diagnostyką i terapią prowadzoną w warszawskiej poradni. Nie zaniedbywał również zaangażowania duszpasterskiego, a powołanie kapłańskie widoczne było we wszystkich jego działaniach, przenikało całe życie i oddziaływało pozytywnie na petentów. Nawet wtedy, gdy pełnił funkcje administracyjne: kierownika katedry, sekcji psychologii czy instytutu, podwładni i przychodzący w różnych sprawach interesanci mieli pewność, że spotykają się z księdzem, a nie tylko z urzędnikiem. W swoich gestach i słowach pełnych ciepła, budzących nadzieję, doceniających, dodających otuchy realizował przedstawione przez 
Karola Wojtyłę powołanie do duchowego promieniowania ojcostwa ${ }^{9}$. Każdego człowieka widział jako godną szacunku istotę cielesno-psychiczno-duchową, mającą relacje społeczne, o które warto się troszczyć.

Ks. Prof. Cekiera, jako psycholog i znawca toksykologii, nie poprzestał na wyjaśnianiu i zapobieganiu narkomanii, czy opisie problemów związanych z nadużywaniem alkoholu, ale zajął się także wielorakimi skutkami palenia tytoniu i przeciwdziałaniem również temu nałogowi. Wyrazem tego są książki: Palenie tytoniu wolność czy zniewolenie ${ }^{10}$; Tytoñ ${ }^{11}$; Papierosy. Palacy problem palenia $^{12}$ oraz referaty konferencyjne poświęcone profilaktyce palenia tytoniu. Pod kierunkiem Ks. Prof. Cekiery powstawały liczne prace magisterskie i doktorskie. Część z nich dotyczyła psychologicznych aspektów problemu palenia tytoniu. Przykładem może być prezentowana w książce Palenie tytoniu wolność czy zagrożenie, oparta na prowadzonych badaniach kwestionariuszowych, praca magisterska Olgi Miech na temat cech osobowości palaczy i abstynentów nikotynowych ${ }^{13}$. Kolejne badania empiryczne, powstałe pod kierunkiem Ks. Profesora dotyczące uzależnienia od tytoniu, opisują korelaty osobowości w wybranych grupach młodzieży ${ }^{14}$, określają poziom neurotyzmu palaczy ${ }^{15}$, zwracają uwage na poczucie zmian obrazu siebie $^{16}$ i potrzebę profilaktyki palenia papierosów w grupie młodzieży ${ }^{17}$.

${ }^{9}$ Napisana przez Karola Wojtyłę sztuka (1964). Jedno z jej wydań to: Karol Wojtyła, Promieniowanie ojcostwa (Wrocław: Wydawnictwo Wrocławskiej Księgarni Archidiecezjalnej TUM, 2007)

${ }^{10}$ Cekiera, Zatoński (red.), Palenie tytoniu wolność czy zniewolenie?

${ }^{11}$ Czesław Cekiera, Tytoń (Lublin: Wydawnictwo KUL, Wydawnictwo „Gaudium”, 2005).

12 Czesław Cekiera, Papierosy. Palacy problem palenia (Toruń: Europejskie Centrum Edukacyjne, 2013).

13 Olga Miech, „Niektóre cechy osobowości palaczy i abstynentów nikotynowych”, opr. Urszula Dudziak, w Palenie tytoniu wolność czy zniewolenie? 59-71.

14 Anna Czalej-Hurko, „Korelaty osobowości a uzależnienie od tytoniu w wybranych grupach młodzieży", w Palenie tytoniu wolność czy zniewolenie?, 53-58.

${ }^{15}$ Teresa Gałązka-Bazydło, „Poziom neurotyzmu u toksykomanów, alkoholików i palaczy”, w Palenie tytoniu wolność czy zniewolenie? 101-117.

16 Barbara Horszko-Szmyd, „Poczucie zmian w obrazie siebie u osób z uzależnieniem nikotynowym, w Palenie tytoniu wolność czy zniewolenie? 119-136; Agnieszka Lalik, „Poczucie zmian obrazu siebie u palącej papierosy młodzieży szkoły średniej”, w Palenie tytoniu wolność czy zniewolenie? 137-174; Katarzyna Rzeszowska, „Obraz siebie u palaczy i inhalantomanów”, w Palenie tytoniu wolność czy zniewolenie? 175-195.

17 Agnieszka Lalik, „Profilaktyka palenia papierosów przez młodzież szkoły średniej”, w Palenie tytoniu wolność czy zniewolenie? 227-252. 
Zagadnienia, związane z uwarunkowaniami i skutkami palenia tytoniu, były również przedmiotem wykładów Ks. Profesora głoszonych dla studentów psychologii i pedagogiki KUL. Wskazanie na potrzebę przeciwdziałania uzależnieniu od nikotyny mogło być istotne dla osobistych decyzji słuchaczy o niepaleniu, mogło też przydać się w ich przyszłej pracy zawodowej. Niektóre absolwentki do dziś wspominają, jak z ojcowską troskliwością, pracujący na KUL do 72 roku życia, wykładowca i promotor prac, zachęcał swe studentki, magistrantki i doktorantki do tego, by na swych przyszłych mężów wybierały kandydatów niepalących.

Szczególnie zasłużony w epidemiologii, promocji zdrowia i profilaktyce palenia tytoniu, specjalista chorób wewnętrznych Profesor Witold Zatoński dał się poznać jako wielki intelektualista, organizator, charyzmatyk, wspaniały planista, umiejący zaangażować do współpracy wielu ludzi z Polski i ze świata, przejawiający ogromny szacunek dla życia i zdrowia człowieka, podejmujący ważne wyzwania z pełną pasją, udzielaną innym. Będąc profesorem medycyny, sam podejmował wiele zadań, ale także potrafił zauważyć, docenić, uznać działalność innych i zmobilizować do jeszcze większej pracy. W realizacji różnorakich działań ujawniał postawę szacunku dla wartości każdego człowieka, umiejętność zachęcania, motywowania, przekonywania, prowadzenia, współdziałania. $\mathrm{W}$ profilaktyce palenia tytoniu i $\mathrm{w}$ ochronie zdrowia przydatna stała się Jego szeroka, wieloaspektowa zdolność wykorzystania różnych umiejętności i form oddziaływań. Profesor Zatoński potrafił skupić wokół istotnej idei liczne grono osób o wielu, różnych talentach, a poprzez dowartościowanie każdej z nich dodać sił do pracy, realizowanej mimo przeszkód i niechęci niejednego środowiska. Profesor stwarzał poczucie bezpieczeństwa, wlewał nadzieję. Jego zapał, przekonanie o ważności podejmowanych działań prozdrowotnych udzielały się wszystkim. Przyjeżdżający na spotkanie $\mathrm{w}$ Warszawie ludzie $\mathrm{z}$ miast, miasteczek i wiosek odjeżdżali $\mathrm{w}$ teren $\mathrm{z}$ nowymi siłami, postanowieniami, z otrzymaną od Profesora radością i zapałem do dalszego zaangażowania $\mathrm{w}$ zadania profilaktyczne. Co więcej, naukowe i praktyczne refleksje, otrzymane inspiracje, prowokowały uczestników konferencji do dalszego myślenia i już po drodze do swych miejscowości rodziły się im nowe pomysły dotyczące tego, co jeszcze można zrobić.

W 1991 r. z inicjatywy Profesora Zatońskiego powstała w Warszawie Fundacja „Promocja zdrowia”, utworzona z zamiarem zmniejszenia „liczby zachorowań na raka płuca, w szczególności poprzez ograniczenie palenia 
i wymuszonej inhalacji dymu tytoniowego wśród Polaków"18. Fundacja prowadzi projekty i badania naukowe, publikuje uzyskane wyniki, współpracuje z krajowymi i zagranicznymi ośrodkami zdrowia publicznego, organizuje profilaktyczne kampanie społeczne, opracowuje i publikuje materiały dydaktyczne, prowadzi zajęcia szkoleniowe ${ }^{19}$. Wraz z Państwową Wyższą Szkoła Zawodową w Kaliszu, Fundacja wydaje swoje własne anglojęzyczne czasopismo naukowe Journal of Health Inequalities. Jest ono poświęcone: ,problemom dotyczącym różnic $\mathrm{w}$ dostępie do zdrowia w Polsce i innych krajach Europy, kluczowym czynnikom kształtującym zdrowie społeczeństwa, a także szerszym kwestiom globalnego zdrowia publicznego"20.

Duże znaczenie społeczne ma edukacyjna działalność Fundacji. Dzięki niej przeszkolono tysiące przedstawicieli zawodów medycznych i pracowników ochrony zdrowia, nauczycieli i działaczy społecznych „w zakresie prewencji pierwotnej, m.in. raka płuca oraz diagnostyki i leczenia zespołu uzależnienia od tytoniu" ${ }^{21}$. Znaczącym osiągnięciem było rozpoczęte na początku XXI wieku popularyzowanie w Polsce Europejskiego Kodeksu Walki z Rakiem². Opracowano programy edukacyjne dla dzieci i młodzieży chroniące przed rakiem poprzez propagowanie zdrowego stylu życia. Zgodnie z informacjami, zamieszczonymi na stronie internetowej Fundacji, „,w wyniku prowadzonych działań na terenie województwa małopolskiego, w realizację działań edukacyjnych zaangażowanych zostało około 75\% szkół, 40\% nauczycieli, 391000 uczniów oraz 150000 rodziców. Na spotkaniu parlamentarzystów europejskich Cancer Prevention: the role of the European Code Against Cancer, które odbyło się 10 grudnia 2014 roku w Brukseli, projekt wdrażania zapisów Europejskiego kodeksu walki z rakiem w Polsce został uznany za najlepszy program budowania kompetencji zdrowotnych w Europie"23.

\footnotetext{
${ }^{18}$ Fundacja „Promocja Zdrowia”, Działania Fundacji (dostęp 07.06.2021), http://promoc jazdrowia.pl/dzialania-fundacji/

${ }^{19}$ Fundacja „Promocja Zdrowia”, Misja i cele (dostęp 09.06.2021), https://promocjazdro wia.pl/misja-i-cele/

${ }^{20}$ Fundacja „Promocja Zdrowia”, Journal of Health Inequalities (dostęp 09.06.2021), https: //promocjazdrowia.pl/jhi-2/

${ }^{21}$ Tamże.

${ }^{22}$ Witold Zatoński (red.), Europejski Kodeks Walki z Rakiem, wydanie polskie na podstawie European code against cancer and scientific justification: third version (Warszawa: Centrum Onkologii - Instytut im. Marii Skłodowskiej-Curie, 2003).

${ }^{23}$ Fundacja „Promocja Zdrowia” (dostęp 07.06.2021), http://promocjazdrowia.pl/dzialaniafundacji/
} 
W związku z głównym zadaniem koncentrowania się na walce z paleniem tytoniu, szczególnymi i mobilizującymi do zwielokrotnionej aktywności były coroczne obchody: Światowego Dnia bez Tytoniu (31 maja) i Światowego Dnia Rzucania Palenia (trzeci czwartek listopada). Akcja „Rzuć palenie razem z nami” wiązała się nie tylko z prezentacją skutków palenia tytoniu, zachętą do abstynencji nikotynowej, troską o niepalących, ale także nagradzaniem tych, którym udało się rzucić palenie. Wylosowani każdego roku abstynenci nikotynowi wraz z ekspertami różnych dziedzin, zaangażowanymi w profilaktykę uzależnienia od tytoniu, wyruszali na wspólną autokarową wycieczkę do Włoch.

Od 1994 roku Fundacja „Promocja Zdrowia” przyznaje „Białe Kruki” nagrody za propagowanie zdrowego stylu życia wolnego od dymu tytoniowego"24. Nagrodę stanowi obraz wykonany przez prof. Andrzeja Pągowskiego i wręczany w Pałacu Prymasowskim w Warszawie przez Prymasa Polski i Prezesa Fundacji „Promocja Zdrowia”. Fakt ten ukazuje współpracę Fundacji z Kościołem, dowodzi uwzględniania w psychoprofilaktyce dwóch konstytuujących człowieka aspektów - ciała i ducha. Takie wyróżnienie dla reprezentantów różnych środowisk z całego kraju stanowiło dodatkową motywację do kontynuacji i intensyfikacji działań profilaktycznych. Wskazywało również na istotę i ważkość problemu palenia tytoniu dotyczącego wszystkich bez wyjątku, zarówno palaczy jak i osób narażonych na bierne palenie. Przyczyniało się do zainteresowania tym problemem wielu grup społecznych, zwiększenia grona osób poznających zagadnienie za pośrednictwem środków społecznego przekazu, jak również samych nagrodzonych powracających z Warszawy do swych rodzin, osób z sąsiedztwa, znajomych, kolegów z różnych miejsc pracy.

Od 1996 r. osoby, popierające działania Fundacji „na rzecz poprawy stanu zdrowia Polaków, a w szczególności za osobisty wkład w kształtowanie pozytywnych zmian w stylu życia Polaków"25, zasłużone w przeciwdziałaniu paleniu tytoniu, są odznaczane przez prezesa Fundacji „Promocja Zdrowia” Złotą Honorową Odznaką. Jej symbolem są ,zdrowe płucka” wykonane z prawdziwego złotego kruszcu z podpisem „Nie palę”. Do wręczanego znaczka dołączany jest imienny certyfikat.

\footnotetext{
${ }^{24}$ Nagrody Fundacji, 09.06.2021, https://promocjazdrowia.pl/nagrody-fundacji/

25 Ztote płucka (dostęp 10.06.2021), https://promocjazdrowia.pl/nagrody-fundacji/
} 


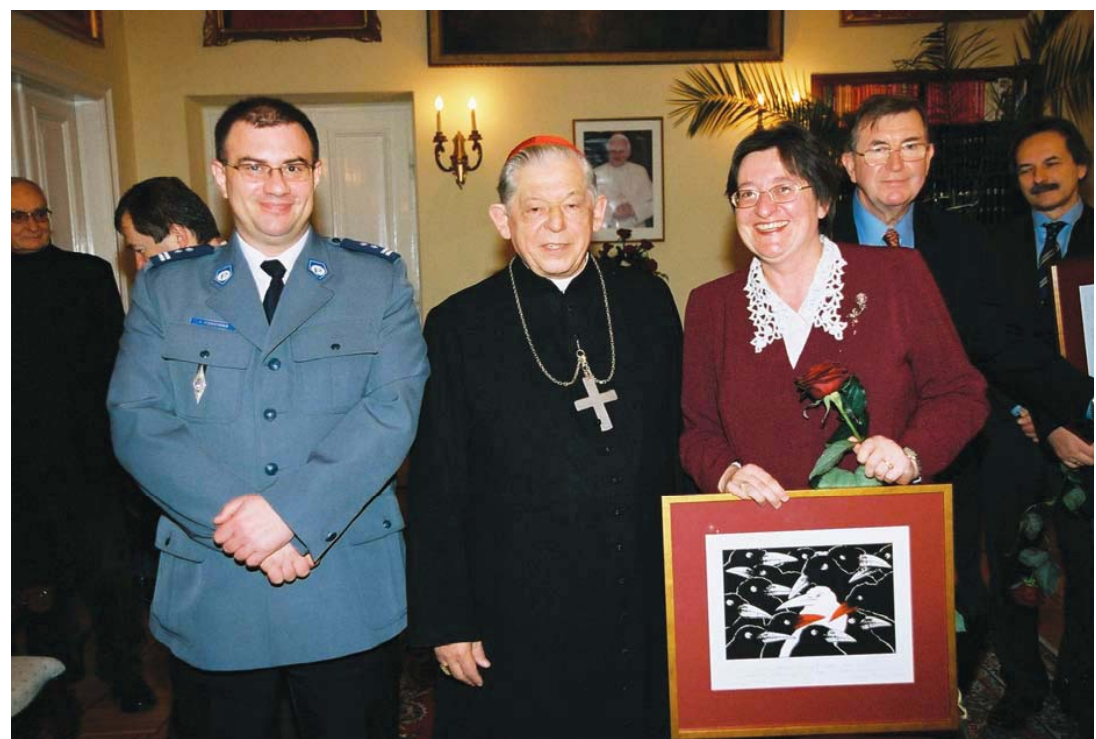

Fot. 1. Nagroda „Białego Kruka” za profilaktykę palenia tytoniu i troskę o zdrowie rodzin

(Warszawa 2006, Źródło: Archiwum autorki).

Od 1998 roku Profesor Witold Zatoński wraz z zespołem współpracowników z Zakładu Epidemiologii i Prewencji Nowotworów warszawskiego Centrum Onkologii - Instytutu Marii Skłodowskiej-Curie i Fundacji „Promocja Zdrowia” zaczął organizować corocznie konferencje naukowe „Tytoń albo zdrowie". Nosiły one imię Prof. Franciszka Venuleta dla upamiętnienia jego pionierskich prac nad szkodliwością dymu tytoniowego dla zdrowia człowie$\mathrm{ka}^{26}$. Konferencje te stały się forum wymiany doświadczeń i integracji środowisk zajmujących się profilaktyką palenia tytoniu, poszerzały wiedzę, wzmacniały motywację działań profilaktycznych, przekonywały o słuszności podejmowanych starań, dodawały sił do dalszej aktywności i zmagania się z nierzadkim brakiem przychylności we własnym środowisku, dodawały otuchy, wsparcia, umocnienia i poczucia przynależności do Zespołu, którym kierował Profesor Zatoński, rodziły świadomość jednomyślności oraz wspólnego służenia sprawie, którą inni również uznają za istotną i potrzebną, budowały więzi pomiędzy osobami zainteresowanymi profilaktyką w Polsce i na świecie.

${ }^{26}$ Andrzej Danysz, „Prof. Franciszek Venulet - pionier polskich badań nad wpływem dymu tytoniowego na stan zdrowia”, Alkoholizm i Narkomania (1999), 3/36: 325-332. 


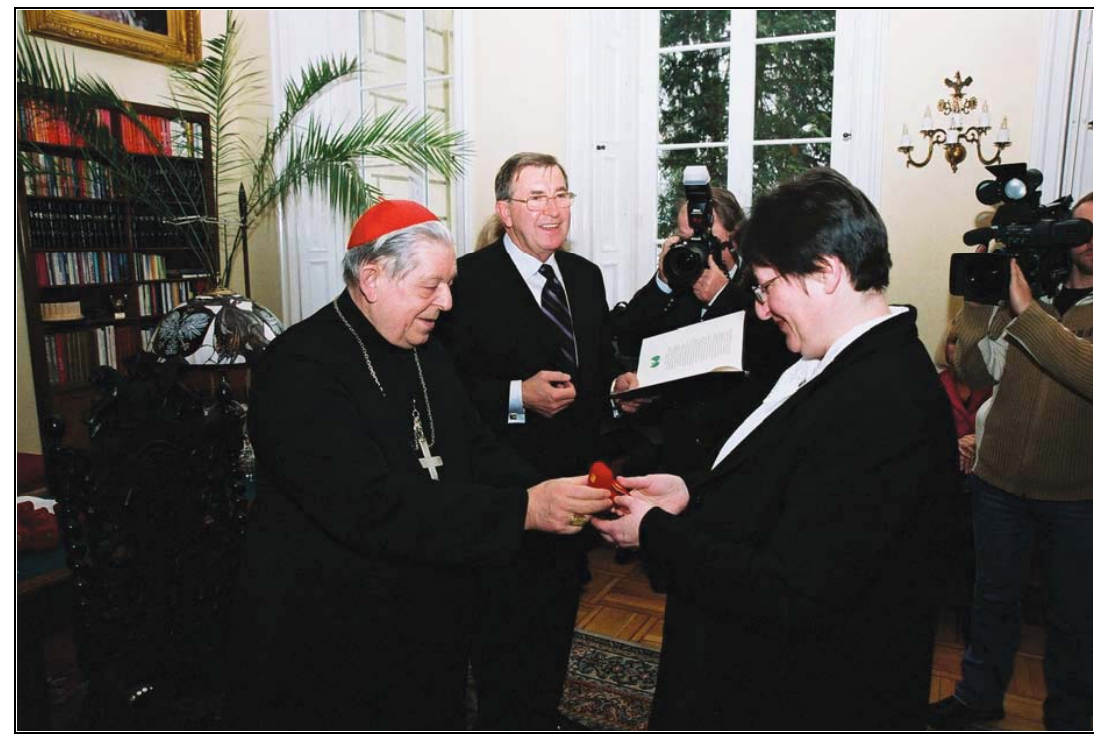

Fot. 2. Wręczanie Złotej Honorowej Odznaki Fundacji „Promocja Zdrowia” (Warszawa 2006, Źródło: Archiwum autorki).

Gromadząc specjalistów różnych dziedzin: kardiologów, pulmonologów, onkologów, stomatologów, dermatologów, ginekologów-położników, farmakologów, laryngologów, psychologów, teologów, pedagogów konferencje pozwalały na wymianę informacji na temat aktualnego stanu badań i w ten sposób ubogacały swych uczestników wielością interdyscyplinarnych treści na temat przyczyn, skutków i sposobów przeciwdziałania paleniu tytoniu. Pozwalały także na nawiązanie współpracy, zarówno z gronem krajowych, jak i zagranicznych naukowców, przedstawicielami rządu i organizacji pozarządowych. Umożliwiały dzielenie się praktycznym doświadczeniem oraz poznanie skuteczności działań profilaktycznych.

Charakterystyczna dla Profesora Zatońskiego była umiejętność tworzenia podczas konferencji bardzo przyjaznej atmosfery. Jak ojciec rodziny skupiał on profilaktyków, inspirował i ukierunkowywał ich działania, dodawał pewności, umacniał, czuwał nad przedsięwzięciami, doradzał, wspierał i cieszył się z rezultatów podejmowanej przez każdego pracy. Mimo że sam robił bardzo dużo, mając liczne kontakty z przedstawicielami różnych środowisk w Polsce i za granicą, to również zauważał i chwalił nawet drobne osiągnięcia innych, cenił zaangażowanie. To dzięki temu profilaktycy czuli się potrzebni, ich aktywność nie ustawała i zaczynała przynosić owoce. Współpracownicy i ludzie $z$ tak zwanego terenu (małych miast i wsi) wiedzieli, że 
mają do kogo się odwołać, powołać na Jego autorytet, zapytać, poradzić. Życzliwość, która się udzielała, przekazywana była dalej i dodawała pewności, że jest się na właściwej drodze i podjęte zadania trzeba i można wykonać jak najlepiej.

Zgodnie ze sprawozdaniem Joanny Fetlińskiej, zamieszczonym w czasopiśmie „Medycyna nowożytna”: „Pierwsza konferencja (16 listopada 1998 r.) odbyła się w 120. rocznicę urodzin prof. Franciszka Venuleta w Warszawie, w Centrum Onkologii - Instytucie im. Marii Skłodowskiej-Curie pod hasłem „Palenie Tytoniu a Zdrowie” i była poświęcona pamięci osoby Profesora oraz prezentacji jego niebagatelnego dorobku naukowego"27. Stanowiły go 103 publikacje, w tym 64 prace oryginalne dotyczące między innymi niekorzystnego wpływu palenia tytoniu na: rozwój organizmu, odporność, wydolność fizyczną, powstawanie nowotworów, funkcje kory nadnerczy oraz poziom witaminy „„”. Ogólnopolskie Konferencje Naukowe „Tytoń albo Zdrowie” odbywały się początkowo w Centrum Onkologii - Instytut im. Marii Skłodowskiej-Curie w Warszawie, przy ul. Roentgena 5, kolejne organizowane były w różnych miastach Polski. W 2002 roku był to Poznań. Konferencja w tym mieście zaowocowała kolejnymi edycjami konferencji realizowanymi w Poznaniu, pod nazwą „Kobieta i Tytoń”. W 2002 i 2003 znów miejscem konferencji była Warszawa, następnie Gdańsk (2004), Radom (2005), Płock (2006), Ciechanów (2007).

X Jubileuszowa Konferencja w Ciechanowie była okazją do podsumowań i tworzenia kolejnych planów działalności profilaktycznej. Podczas poprzedniej konferencji w Płocku postulowano: „strategie wprowadzenia zakazu palenia tytoniu w miejscach publicznych i zakładach pracy, podwyższenia cen na papierosy, skupienia programów prewencyjnych szczególnie na młodych kobietach i ciężarnych, ochrony dzieci przed biernym paleniem, adresowania działań edukacyjnych do gorzej wykształconych i biedniejszych warstw społecznych, rozbudowania systemu leczenia uzależnionych od tytoniu" ${ }^{\prime 2}$. Na dwudniowej konferencji w Ciechanowie podtrzymano i ukonkretniono potrzebę wprowadzenia zakazu palenia tytoniu $w$ miejscach publicznych, barach i restauracjach. Podjęto też wyzwanie właściwego przygotowania odpowiedniej nowelizacji ustawy o ochronie zdrowia przed skutkami używania tytoniu i efektywnego jej wdrożenia, tak ,,aby bierne palenie zagrażało jak najmniej-

\footnotetext{
27 Janina Fetlińska, „Problemy zwalczania palenia tytoniu w Polsce: sprawozdanie z dziesięciu Ogólnopolskich Konferencji Naukowych im. Prof. Franciszka Venuleta (lata 1998-2007)” Medycyna Nowożytna 15(2008), 1-2: 189.

28 Tamże, 196.
} 
szej grupie osób"29. Podsumowując 10 konferencji „Tytoń albo Zdrowie” Janina Fetlińska stwierdziła, że zarówno liczba słuchaczy, jak i chętnych do wygłoszenia referatu wciąż wzrasta. Potrzeba wzajemnych kontaktów, wymiany danych naukowych i informacji o dokonaniach jest nadal znaczna. Zapoczątkowane dzieło było więc kontynuowane w kolejnych latach i miejscach: Łódź (2008), Kraków (2009), Kielce (2010), Warszawa (2011), Warszawa Wszechnica Polska Szkoła Wyższa w Warszawie (2012), Wrocław (2013), Tarnów (2014), Warszawa - Instytutu Biocybernetyki i Inżynierii Medycznej (2015), Poznań (2016).

Gdy w czerwcu 2003 roku powstała Obywatelska Koalicja „Tytoń albo zdrowie", Profesor Witold Zatoński został jednomyślnie wybrany jej Honorowym Przewodniczącym. Miesiąc później polska Koalicja „została członkiem Europejskiej Sieci na rzecz Ograniczania Palenia (European Network for Smoking Prevention/ENSP"30. Koalicja zrzesza organizacje zajmujące się polityką zdrowotną, zabiegające o prawidłowe funkcjonowanie kolejnych ustaw przeciwdziałających paleniu tytoniu, a w szczególności o realizację opartych na niej Programów zatwierdzonych przez Prezesa Rady Ministrów na kolejne lata. Fundacja „Promocja Zdrowia” należąca do Koalicji i będąca jej głównym członkiem założycielem, poprzez swą działalność, w wydatny sposób przyczyniła się do uchwalenia ustawy antytytoniowej ${ }^{31}$ nazwanej w Światowej Organizacji Zdrowia „przykładem dla reszty świata”32. Była to „Ustawa sejmowa $\mathrm{z}$ dnia 9 listopada 1995 r. o ochronie zdrowia przed następstwami używania tytoniu i wyrobów tytoniowych"33, po latach aktualizowana i obecnie obowiązująca z uzupełnieniami.

Współpracownicy Prof. Zatońskiego, czerpiąc wzór ze swego mentora, również odznaczali się wysokim zaangażowaniem w ochronę życia i zdrowia Pola-

\footnotetext{
29 Tamże, 197.

${ }^{30}$ Małgorzata Misiuna, „Obywatelska Koalicja «Tytoń albo Zdrowie»” w X Ogólnopolska Konferencja Naukowa im. prof. Franciszka Venuleta „Tytoń albo Zdrowie” Płock 07-08 listopada 2006. Materiały konferencyjne (Płock: Centrum Psychologiczno-Pastoralne Metanoja, 2006), 8.

${ }^{31}$ Mateusz Zatoński, „Marking the 20th anniversary of the Polish Anti-Tobacco Law”, Journal of Health Inequqlities 2(2016): 110.

32 Douglas Blanke, Vera de Costa e Silva "Tools for advancing tobacco control in the 21st century. Tobacco Control Legislation: An introductory guide” (Geneva: World Health Organization, 2004).

${ }^{33}$ Ustawa z dnia 9 listopada 1995 r. o ochronie zdrowia przed następstwami używania tytoniu i wyrobów tytoniowych (Dz. U. 1996, Nr 10, poz. 55); Data wejścia w życie: 1 maja 2016; Wejście w życie ostatniej zmiany 11 lutego 2021, Dz. U. 2021, poz. 276.
} 
ków. Działania Profesora wspierał, udzielał się przy organizacji konferencji i opisywał narodowe kampanie Janusz Marek Jaworski ${ }^{34}$. Znaczący wpływ na późniejszy zakaz palenia tytoniu w miejscach publicznych miały rozpoczęte w 2006 roku przez Krzysztofa Przewoźniaka badania nad wielokrotnie przekraczającym dopuszczalne normy zanieczyszczeniem powietrza przez dym tytoniowy w klubach muzycznych i dyskotekach, barach i restauracjach ${ }^{35}$.

Profesor medycyny Witold Zatoński swą wiedzę o tym, jak szerzy się choroba, umiejętnie wykorzystywał w przedsięwzięciach mających na celu zatrzymanie epidemii palenia tytoniu i w staraniach o uzdrowienie osób uzależnionych. Wlewając swój zapał, pasję, wiedzę i umiejętności w przybywających na coroczne spotkania uczestników naukowych konferencji oraz równie częste spotkania Akcji „Rzuć palenie razem z nami” sprawiał, że profilaktyka palenia tytoniu obejmowała cały kraj i znajdowała naśladowców za granicą.

\section{PROFILAKTYKA INTEGRALNA}

Wartością podjętej przez Profesora i Jego Zespół profilaktyki jest jej integralność. Obejmuje ona całego człowieka w sferze somatycznej, psychicznej, duchowej i społecznej. Pozwala to uwzględnić ludzkie potrzeby ze wszystkich sfer, bez pomijania którejkolwiek z nich, a przez to wzmocnić skuteczność rozmaitych form profilaktycznych. Dzięki temu również do zadań profilaktycznych można zaangażować każdego, o różnym poziomie i rodzaju wykształcenia. W gronie współpracowników Profesora i uczestników organizowanych przez niego konferencji znaleźli się specjaliści różnych dziedzin. Byli wśród nich: lekarze, pielęgniarki, psycholodzy, teolodzy, pedagodzy, nauczyciele, księża, dziennikarze, prawnicy, socjolodzy, artyści. Każdy czuł się potrzebny, każdy

34 Janusz Marek Jaworski, Dorota Linke-Drzyżdżyk, Krzysztof Przewoźniak i Witold Zatoński, „Profilaktyka chorób odtytoniowych - narodowe kampanie zdrowotne”, w Palenie tytoniu w Polsce: postawy, następstwa zdrowotne i profilaktyka, red. Witold Zatoński, Krzysztof Przewoźniak (Warszawa: Centrum Onkologii, 1999), 281-294; Janusz Marek Jaworski, Krzysztof Przewoźniak, Witold Zatoński, „15. lecie kampanii zdrowotnej «Rzuć palenie razem z nami» sukcesy i wyzwania, w IX Ogólnopolska Konferencja Naukowa im. prof. Franciszka Venuleta „Tytoń albo Zdrowie” Ptock 07-08 listopada 2006, Materiaty konferencyjne, 28.

${ }^{35}$ Krzysztof Przewoźniak, Jakub Gumkowski, Małgorzata Zagroda, Paweł Polak, Sylwia Kolakowska, Barbara Witeska, Daniel Pokrywczyński, Janina Fetlińska i Witold Zatoński, „Zanieczyszczenie miejsc publicznych w Polsce dymem tytoniowym”, w IX Ogólnopolska Konferencja Naukowa im. prof. Franciszka Venuleta „Tytoń albo Zdrowie” Płock 07-08 listopada 2006, Materiaty konferencyjne, 29. 
dawał swój własny wkład, stanowiący - przy odmienności i różnorodności wykształcenia - możliwość uzupełniania poznawanych treści i zastosowań, tworząc kompletną interdyscyplinarną całość. Różnorodne talenty i umiejętności stwarzały bogactwo oddziaływań. Różnorodne też były metody docierania do odbiorców: publikacje naukowe i popularne, książki, artykuły, ulotki, filmy, spoty reklamowe, plakaty, kalendarze, konferencje, szkolenia, wykłady, warsztaty, prezentacje, krótkie komunikaty z badań, spotkania, narady, rozmowy przy wspólnym obiedzie i w kuluarach konferencyjnych, grupowe wyjazdy.

W związku z tym, że palenie tytoniu szkodzi nie tylko społeczeństwu jako całości, ale i pojedynczemu człowiekowi, nie tylko dorosłemu, ale (jeszcze bardziej) dziecku, nie tylko w sferze ciała, ale również psychiki i ducha, potrzebna jest profilaktyka uwzględniająca te wszystkie wymiary łącznie. Dotyczy więc ona ludzi w różnym wieku, począwszy od poczęcia - lub nawet wyprzedzających poczęcie, poprzez tak zwaną opiekę prekoncepcyjna podejmowana przez przyszłych rodziców - z uwzględnieniem pozyskiwania wiedzy, formowania nastawień, respektowania zasad moralnych i postępowania zgodnego $\mathrm{z} \mathrm{nimi}^{36}$.

$\mathrm{Z}$ tych powodów pierwsze zaproszenie, jakie Profesor Zatoński skierował do mnie, wiązało się z wygłoszeniem referatu pt. „Czy palenie tytoniu przez kobiety w ciąży jest grzechem? Natomiast Księdza Profesora Cekierę poprosił o przedstawienie szerszego tła tego zagadnienia, z uwzględnieniem innych osób, nie tylko kobiet oczekujących narodzin dziecka. Powierzony Księdzu temat dotyczył duchowej sfery chrześcijanina i miał bardziej ogólnie i całościowo odpowiedzieć na pytanie: Czy palenie tytoniu jest grzechem? Profesor uznał, że to właściwa prośba wobec psychologów i teologów - pracowników Katolickiego Uniwersytetu Lubelskiego, a my staraliśmy się nie zawieść Jego oczekiwań. Potem nastąpiły kolejne wspólne dzieła, obejmujące kilkanaście lat współpracy. Ich rezultatem były, między innymi, publikacje skierowane do osób przygotowujących się do małżeństwa ${ }^{37}$ i doradców życia rodzinnego $^{38}$ oraz nauczycieli - wychowawców odpowiedzialnych za wychowanie dzieci realizowane w szkole ${ }^{39}$.

\footnotetext{
${ }^{36}$ Dudziak, „Dziecko zagrożone dymem tytoniowym”, 129-139.

${ }^{37}$ Urszula Dudziak, Na nowej drodze życia bez papierosa (Poznań: Fundacja „Glos dla Życia", 2002).

${ }^{38}$ Urszula Dudziak, Na nowej drodze życia bez papierosa. Materiaty dla doradców życia rodzinnego (Poznań: Fundacja „Glos dla Życia”, 2002).

${ }^{39}$ Urszula Dudziak, Nauczyciel a profilaktyka palenia tytoniu - Przewodnik (Warszawa: Fundacja „Promocja Zdrowia”, 2006).
} 
Realizowana przez Profesora Zatońskiego profilaktyka palenia tytoniu obejmowała każdą ze sfer i dziedzin życia. Ogarnięcie wszystkich aspektów człowieczeństwa wykluczało redukcjonizm, zapewniało pełnię i intensywność docierających wszędzie oddziaływań, a tym samym gwarantowało ich skuteczność. Szczególnie doceniam fakt, że Profesor Zatoński, będąc lekarzem, nie ograniczał swego patrzenia na pacjenta do sfery chorego ciała, uzależnionego mózgu i medycznych następstw uzależnienia, ale widział go w całości psychiczno-duchowej i społecznej. Stanowiło to praktyczne wcielanie prawdy wyrażonej w sentencji, że ,albo profilaktyka będzie integralna, albo jej wcale nie będzie" ${ }^{40}$. Przykładem tego była dbałość Profesora nie tylko o eliminację nałogu, ale także zdrowy styl życia ujawniający się w prawidłowej diecie, podejmowanym ruchu, pokoju ducha. Wyrazem tego jest „Program Edukacji Tłuszczowej”, „Jedz 5 razy dziennie warzywa i owoce”, „Biegam... więc jestem”41.

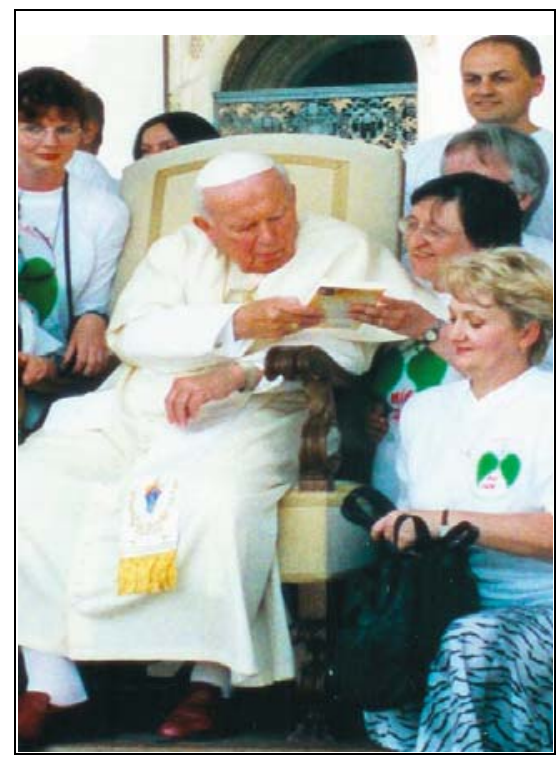

Fot. 3. Fundacja „Promocja Zdrowia” u Jana Pawła II po umocnienie w profilaktyce i abstynencji tytoniowej (Watykan 2002. Źródło: Archiwum autorki)

${ }^{40}$ Sentecję tę uznają za podstawę profilaktyki integralnej tacy profilaktycy, jak: Marek Dziewiecki, Profilaktyka integralna (Kraków: Rubikon, 2007); Szymon Grzelak, Profilaktyka ryzykownych zachowań seksualnych (Kraków: Rubikon, 2009), Krzysztof Wojcieszek, „Mity i zasady profilaktyki uzależnień”, Remedium 5(2002): 16-18.

${ }^{41}$ Fundacja „Promocja Zdrowia” (dostęp 07.06.2021, http://promocjazdrowia.pl/dzialaniafundacji/ 
Dowodem integralności działań, obejmujących sferę somatyczną, psychiczną, duchową i społeczną, były akcje „Rzuć palenie razem z nami” oraz towarzyszące im nagrody związane $\mathrm{z}$ wyjazdem do Watykanu i uzyskaniem dla rzucających palenie duchowego umocnienia, a dla pracowników wsparcia w kontynuacji profilaktycznego dzieła.

O szerokości oddziaływań, oprócz objęcia nimi wszystkich sfer egzystencji człowieka, świadczy: - zaangażowanie do współpracy specjalistów wielu dziedzin; - skierowanie psychoprofilaktyki do osób w różnym wieku i w różnych grupach społecznych: uczniów, studentów, pracowników naukowych, narzeczonych, pracowników służby zdrowia, księży, penitentów, dziennikarzy, artystów; - wykorzystanie różnych form oddziaływań: naukowych, medialnych, artystycznych, medycznych, psychologicznych, duszpasterskich, socjologicznych itp.

Tak, jak wolność od uzależnień, tak i uleganie im kształtuje sposób postępowania w poszczególnych dziedzinach życia. Nałóg palenia tytoniu negatywnie rzutuje na relacje $\mathrm{z}$ innymi. Poszczególne grupy społeczne moga też udzielać pomocy uzależnionemu, wspierając go w wychodzeniu $\mathrm{z}$ nałogu. Szymon Grzelak pisze, że pierwszym źródłem ochrony człowieka przez złem jest miłość Boża, kolejnym miłość małżeńska i rodzicielska, a także najbliższe środowisko, które stanowi dalsza rodzina, przyjaciele, koledzy, sąsiedzi, szkoła, parafia ${ }^{42}$. Zapobieganie uzależnieniu, pomoc wyjścia z niego i wsparcie, by ponownie nie sięgnąć po środek uzależniający, niosą też indywidualni doradcy, terapeuci, organizacje, ustawodawcy stanowiący właściwe prawo chroniące przed zagrożeniami i ryzykownymi zachowaniami, a także środowisko respektujące potrzebne prawa i zalecenia. „Każdego roku istotną informacją dla rzucających palenie i osób ich wspierających są daty ogólnopolskich akcji promujących zdrowy styl życia"43. Społeczeństwo potrzebuje akcji profilaktycznych, potrzebuje kompetentnych osób, których wiedza i autorytet pomoże sprzeciwić się sięganiu po papieros. Potrzebują przykładu asertywnego odmawiania palenia tytoniu i wiedzy o tym, że dym papierosowy zawiera tysiące substancji toksycznych, rakotwórczych i po prostu szkodliwych $^{44}$. Gdy jedni dbają o rynki zbytu dla papierosów i swym działaniem

42 Szymon Grzelak, „Czwarte ogniwo profilaktyki”, Remedium 7-8(2001): 8.

${ }^{43}$ Krzysztof Przewoźniak, ,«Rzuć palenie razem z nami» - kampania zdrowotna dla rzucających palenie - Zdrowie w ciąży - uzależnienia od alkoholu, tytoniu i narkotyków”, 2 maja 2017; https://www.zdrowiewciazy.pl/uzaleznienia-w-ciazy/uzaleznienie-od-tytoniu/369-rzuc-pa lenie-razem-z-nami-kampania-zdrowotna-dla-rzucajacych-palenie (dostęp 10.06.2021).

${ }^{44}$ Andrzej Starek, „Toksykologia dymu tytoniowego”, w Zdrowotne nastęstwa palenia tyto- 
zachęcają do palenia tytoniu, inni powinni coraz liczniej włączyć się w promocję cielesnego i duchowego zdrowia szerząc modę na niepalenie.

\section{REZULTATY DZIAŁAŃ}

Istotną wartością w pracy Fundacji „Promocja Zdrowia” była naukowo-badawcza podbudowa projektów działań uzyskiwana w ramach realizacji międzynarodowych badań podejmowanych przez Centrum Onkologii w Warszawie. Współpracownicy prof. Zatońskiego porównywali problem palenia tytoniu i jego skutki w Polsce $\mathrm{z}$ odnośnymi parametrami w innych krajach $^{45}$. Najpierw więc przeprowadzali badania, interpretowali je pod względem ilościowym i jakościowym, wyciągali wnioski i dopiero potem, na ich podstawie, formowali uzasadnione postulaty działań profilaktycznych. Zbierali też oparte na doświadczeniu wypowiedzi osób zaangażowanych w profilaktykę palenia tytoniu w różnych środowiskach z całego kraju. Te wszystkie dane mogły stanowić niepodważalny argument w rozmowach w Ministerstwie Zdrowia i Komisjach Sejmowych.

Postulat zakazu palenia w miejscach publicznych poprzedzony został badaniami „,w ramach międzynarodowego projektu koordynowanego przez Roswell Park Cancer Institute (USA) oraz Międzynarodową Agencję Badań nad Rakiem (Francja)" prowadzonymi w 60 miejscach czterech miast. Badania dotyczyły pomiaru stężenia dymu tytoniowego i wykonywane były za pomoca monitora TSI Site-Pack umożliwiającego ocenę koncentracji cząsteczek dymu $\mathrm{w}$ powietrzu ${ }^{46}$. Przeprowadzone przez 9 badaczy wyniki badań referował Krzysztof Przewoźniak podczas IX Ogólnopolskiej Konferencji im. prof. Franciszka Venuleta „Tytoń albo zdrowie” w Płocku. Prelegent nawiązał do ogólnopolskich danych wskazujących, że 21\% dorosłych niepalących Polaków jest narażonych na wdychanie dymu tytoniowego w miejscach publicznych. Natomiast ekspozycja dzieci na dym tytoniowy jest znacznie większa i wyno-

niu w Polsce, red. Witold Zatoński, Krzysztof Przewoźniak (Warszawa: Ariel, 1992), 61-73; Witold Zatoński, Krzysztof Przewoźniak, ,Zawartość substancji smolistych sprzedawanych w Polsce w latach 1983-2000”, Zdrowie publiczne i zarzadzanie 7(2009), 2: 12-19; „Palenie tytoniu i Ty. Składniki dymu tytoniowego", http://palenie.doktorzy.pl/dym.htm (dostęp 10.06.2021).

${ }^{45}$ Witold Zatoński, Krzysztof Przewoźniak, Urszula Sulkowska, Robert West, Andrzej Wojtyła, „Tobacco smoking in countries of the European Union”, Annals of Agricultural and Environmental Medicine 19(2012), 2: 181-192.

46 Przewoźniak i in. „Zanieczyszczenie miejsc publicznych”, 29. 
si aż 75-87\%. W wystąpieniu zwrócił uwagę, że z przeprowadzonych badań wynika, iż największe stężenie dymu tytoniowego występuje w klubach muzycznych i dyskotekach. Zanieczyszczenie powietrza w pubach i restauracjach jest szczególnie szkodliwym czynnikiem w pracy kelnerek, którymi często są młode kobiety w okresie prokreacyjnym, dotyczy to również dzieci w okresie prenatalnym w sytuacji, gdy ich mamy, będąc w ciąży, kontynuują pracę w takich warunkach ${ }^{47}$.

Od 15 listopada 2010 r. wszedł zakaz palenia wyrobów tytoniowych w miejscach publicznych. Złamanie tego zakazu karane jest grzywną w wysokości 500 zł. Obowiązujący od 11 lutego 2021 roku artykuł 5 „Ustawy o ochronie zdrowia przed następstwami używania tytoniu i wyrobów tytoniowych" podtrzymał zakaz palenia wyrobów tytoniowych, w tym palenia nowatorskich wyrobów tytoniowych, i palenia papierosów elektronicznych: na terenie zakładów leczniczych podmiotów leczniczych i w pomieszczeniach innych obiektów, w których są udzielane świadczenia zdrowotne; na terenie jednostek organizacyjnych systemu oświaty, o których mowa w przepisach o systemie oświaty, oraz jednostek organizacyjnych pomocy społecznej, o których mowa w przepisach o pomocy społecznej; na terenie uczelni; w pomieszczeniach zakładów pracy innych niż wymienione w pkt. 1 i 2 ; w pomieszczeniach obiektów kultury i wypoczynku do użytku publicznego; w lokalach gastronomiczno-rozrywkowych; w środkach pasażerskiego transportu publicznego oraz w obiektach służących obsłudze podróżnych; na przystankach komunikacji publicznej; w pomieszczeniach obiektów sportowych; w ogólnodostępnych miejscach przeznaczonych do zabaw dzieci; w innych pomieszczeniach dostępnych do użytku publicznego.

Kontrola i promocja zakazu palenia tytoniu prowadzona przez Państwowa Inspekcję Sanitarną, porównując dane z roku 2009 i 2011, wykazała zmniejszone narażenie na bierne palenie w miejscach publicznych ${ }^{48}$ „Największy, ponad dwukrotny, spadek narażenia odnotowano w lokalach gastronomicznorozrywkowych (z 36\% w 2009 r. do 14\% w 2011 r.)" ${ }^{49}$. W barach i pubach z 39\%-20\%; kawiarniach 39\%-12\%; restauracjach 31\%-10\%; dyskotekach i klubach muzycznych $34 \%-16 \%$; zakładach pracy $32 \%-14 \%$; obiektach sportowych 23\%-13\%; placówkach edukacyjnych 12\%-8\%; środkach transportu

\footnotetext{
47 Tamże.

${ }^{48}$ Kontrola i promocja zakazu palenia tytoniu prowadzona przez Państwowa Inspekcje Sanitarna (Warszawa: Główny Inspektorat Sanitarny, 2012).

${ }^{49}$ Program Ograniczania Zdrowotnych Nastęstw Palenia Tytoniu w Polsce. Cele i zadania na lata 2014-2018, opr. Minister Zdrowia (Warszawa: Rada Ministrów, 2013), 8.
} 
publicznego 17\%-7\%. Znaczny spadek, ale jednocześnie nadal wysokie zagrożenie substancjami toksycznymi znajdującymi się w dymie tytoniowym, wchłanianymi poprzez tak zwane bierne palenie, stwierdzono na przystankach i innych obiektach komunikacji miejskiej $47 \%-31 \%^{50}$.

W 2016 r. Rada Ministrów przedłożyła Sejmowi Rzeczypospolitej Polskiej opracowane przez Głównego Inspektora Sanitarnego Sprawozdanie z realizacji Programu ograniczania zdrowotnych następstw palenia tytoniu w Polsce w 2014 roku". Przedstawiono w nim również wyniki badań porównawczych wskazujących na pozytywne zmiany w zachowaniach Polaków. Prowadzone w 2006 i 2014 roku ogólnopolskie badania osób mających 18 lat i więcej, w grupach liczących 8000 respondentów, na temat postaw Polaków wobec palenia tytoniu wykazały, że odsetek osób palących papierosy spadł z $29 \%$ do $23 \%$. Zmniejszyło się także narażenie osób niepalących na bierne palenie. „W 2006 r. aż 53\% palących przyznało, że pali często w obecności niepalących, w 2014 r. odsetek ten był ponad dwa razy mniejszy (24\%)". Rezultat ten można przypisać akcjom edukacyjnym i wprowadzonemu w 2010 roku zakazowi palenia w miejscach publicznych. W 2015 r. rozpoczęła funkcjonowanie Ogólnopolska Sieć Pomocy Palącym, w ramach której otwarto punkty poradniane oferujące pomoc w rzuceniu palenia, dystrybuujące ulotki, plakaty antynikotynowe, szerzące $\mathrm{w}$ środkach społecznego przekazu informacje dotyczące profilaktyki palenia tytoniu. W Sprawozdaniu podsumowano, że: „W okresie realizacji Programu OSPP w punktach przyjęto 399 pacjentów, którym udzielono łącznie 835 porad. Spośród osób przyjętych w punktach OSPP: 173 deklarowały ograniczenie palenia, a 52 odstawiły papierosy"51.

Kolejnym problemem, rozpatrywanym od dłuższego czasu, była sprawa reklam papierosów. Z medycznego i moralnego punktu widzenia do używania substancji zagrażających zdrowiu i życiu powinno się raczej zniechęcać, niż zachęcać. Innego, motywowanego finansowo, zdania może być w tej kwestii grupa producentów i sprzedawców tytoniu. W tej sytuacji, dla przekonania ustawodawców konieczne stały się, oparte na faktach, analizy i konkretne badania naukowe. W latach 90 . XX wieku znacząco wzrosła reklama papierosów kierowana do kobiet i dziewcząt. Ogólnokrajowe badanie postaw dzieci w wieku szkolnym wobec palenia WHO Survey on Health Behaviors Among Schoolchildren (HBSC) 1990-2002, referowane przez Krzysztofa Przewoźnia-

\footnotetext{
${ }^{50}$ Tamże.

${ }^{51}$ Główny Inspektorat Sanitarny, Sprawozdanie z realizacji Programu ograniczania zdrowotnych następstw palenia tytoniu w Polsce w 2015 roku (Warszawa: Rada Ministrów, 2016).
} 
ka podczas konferencji w Płocku, wykazały gwałtowny wzrost odsetka palących tytoń 15-letnich dziewcząt. Częściowy zakaz reklam okazał się nieskuteczny. Natomiast zakaz całkowity, zarówno na ulicznych bilbordach, jak i w prasie sprawił, że wzrost palenia tytoniu przez dziewczęta w wieku 11-15 lat został zatrzymany. Przeprowadzone w 2003 roku badania Global Youth Tobacco Survey (GYTS) potwierdziły, że 42\% dzieci w wieku 13-15 lat nie rozpoczęło palenia ${ }^{52}$.

Po ocenie wpływu reklam na decyzję sięgania po papieros, Prof. Zatoński i jego współpracownicy podjęli starania o zamieszczenie na paczkach papierosów graficznych ostrzeżeń o szkodliwości palenia. W przeprowadzonym wywiadzie, Krzysztof Przewoźniak z Centrum Onkologii w Warszawie reprezentujący Koalicję Obywatelską „Tytoń albo zdrowie” stwierdził, że wnioski z ponad 100 badań naukowych dowodzą, że „najskuteczniejsze są ostrzeżenia obrazkowe o bardzo dużej powierzchni (przekraczającej 50 proc. przedniej i tylnej strony opakowania papierosów), które pokazują prawdziwe skutki palenia, tzn. raka, udar mózgu czy przedwczesną śmierć" ${ }^{53}$. Dodał też, że „po wprowadzeniu ostrzeżeń obrazkowych na paczkach papierosów przynajmniej pół miliona palaczy w Polsce, w większości ludzi młodych, może rzucić palenie lub go nie rozpocznie. Ponadto, Polacy maja prawo zobaczyć co im grozi, zanim zdecyduja się na rozpoczęcie palenia lub będą je kontynuować, a nie tylko polegać na informacji podawanej przez producenta, który jest zainteresowany sprzedażą jak największej ilości papierosów - produktu uznanego przez Międzynarodową Agencję Badań nad Rakiem za jeden z najbardziej rakotwórczych" ${ }^{, 5}$.

W „Ustawie o ochronie zdrowia przed następstwami używania tytoniu i wyrobów tytoniowych" z obowiązującymi od 11 lutego 2021 roku zmianami, wymóg dotyczący obrazkowych ostrzeżeń o szkodliwości palenia został podtrzymany. Zgodnie z zapisem artykułu 9b wyżej wymienionej ustawy, na każdym opakowaniu papierosów wymagane są ostrzeżenia tekstowe wraz z fotografią z załączonej biblioteki obrazów adekwatną do tekstu, a także informacją, gdzie można się udać w celu uzyskania pomocy w pozbyciu się

\footnotetext{
${ }^{52}$ Krzysztof Przewoźniak, Witold Zatoński, „Zakaz reklamy tytoniu w Polsce i jego wpływ na postawy młodzieży wobec palenia tytoniu”, w IX Ogólnopolska Konferencja Naukowa im. prof. Franciszka Venuleta „Tytoń albo Zdrowie” Ptock 07-08 listopada 2006, 27.

${ }^{53}$ Beata Drewnowska, „Obrazkowe ostrzeżenia na papierosach w Polsce” 10.10.2011 (dostęp 10.06.2021, https://www.rp.pl/artykul/730642-Obrazkowe-ostrzezenia-na-papierosach-wPolsce.html

54 Tamże.
} 
nałogu. Artykuł precyzuje wielkość i rozmiar wymaganych ostrzeżeń stanowiących swoistą antyreklamę palenia (65\% zewnętrznego obszaru zarówno przedniej, jak i tylnej płaszczyzny opakowania jednostkowego i opakowania zbiorczego, w przypadku opakowań jednostkowych papierosów mają wysokość nie mniejszą niż $44 \mathrm{~mm}$, szerokość nie mniejszą niż $52 \mathrm{~mm}^{55}$.

Profesor Witold Zatoński podał do wiadomości, że kampanie społeczne, a wśród nich zwłaszcza kolejne edycje akcji „Rzuć palenie razem z nami” przyczyniły się do rezygnacji $\mathrm{z}$ palenia tytoniu 4 milionów Polaków ${ }^{56}$. W „Apelu z okazji Światowego Dnia Rzucania Palenia”, porównując dane z roku 2009 i 2016, wskazał na trzy istotne zmiany. Pierwszą z nich była zmniejszona liczba sprzedanych papierosów z ponad 100 mld w 2009 roku do ok. 40 mld. w 2016 roku. Drugą - zmniejszona umieralność mężczyzn w średnim wieku z 60/100 000 do 20/100 000. Trzecią - mniejsza o 2/3 umieralność z powodu raka płuc, który zaliczany jest do głównej z chorób odtytoniowych. Profesor konstatuje, że „Polska stała się liderem walki z rakiem płuc na świecie" ${ }^{, 57}$. Badania porównawcze z poprzednich lat dają podobne wyniki, co świadczy o korzystnym trendzie ${ }^{58}$. Istotne jest utrzymanie, a nawet zintesyfikowanie tej tendencji spadkowej, co w sytuacji problemów wywołanych przez pandemię Covid-19 i zwiększającej się skali uzależnień od Internetu może być trudne. Pozytywne byłoby, byśmy biorąc przykład ze Stolicy Apostolskiej uznali, że „żaden zysk nie może być zasadny, jeśli kosztem jest życie ludzkie" ${ }^{, 59}$. Papież Franciszek przyjmując takie stanowisko

55 Art. 9b. „Ostrzeżenia zdrowotne na opakowaniach wyrobów tytoniowych” Ustawy o ochronie zdrowia przed następstwami używania tytoniu i wyrobów tytoniowych. Dz. U.2021 poz. 276 Wersja obowiązująca od 11 lutego 2021 r.

${ }^{56}$ Fundacja „Promocja Zdrowia”, O Fundacji. Nasze działania (dostęp 10.06.2021), https:// promocjazdrowia.pl/nasze-dzialania/

${ }^{57}$ Witold Zatoński, Apel z okazji Światowego Dnia Rzucania Palenia (dostęp 10.06.2021), https://promocjazdrowia.pl/apel-fundacji-promocja-zdrowia-z-okazji-swiatowego-dnia-rzucaniapalenia/\#_ftnref1

${ }^{58}$ Zatoński, Przewoźniak, Sulkowska, West, Wojtyła, „Tobacco smoking in countries of the European Union", 181-192; Zob. też Janusz Czapiński, Tomasz Panek (red.), Diagnoza Spoteczna 2013. Warunki i jakość zycia Polaków. Raport (Warszawa: Ministerstwo Pracy i Polityki Społecznej, Centrum Zasobów Ludzkich, 2014), 265-268; Witold Zatoński, Urszula Sulkowska, Joanna Didkowska, „Kilka uwag o epidemiologii nowotworów w Polsce”, Nowotwory Journal of Oncology 65(2015), 3:179-196. Witold Zatoński, Demokracja jest zdrowsza: cud zdrowotny nad Wisła, (Warszawa: Centrum Onkologii - Instytut, 2004).

59 Fundacja „Promocja Zdrowia”, Żaden zysk nie może być zasadny, jeśli kosztem jest życie ludzkie. Zakaz sprzedaży papierosów w Watykanie, 10 czerwca 2021 (dostęp 10.06.2021), https://promocjazdrowia.pl/zakaz-sprzedazy-papierosow-w-watykanie/ 
„zdecydował, że Stolica Apostolska nie może uczestniczyć w działalności, która «wyraźnie szkodzi zdrowiu ludzi» i od 1 stycznia 2018 roku wprowadził zakaz sprzedaży papierosów na terenie Watykanu"60.

Doceniając aktywność profilaktyków w Polsce i rezultaty prowadzonych działań, należy stwierdzić ich stała aktualność i nieodzowność. Ma to znaczenie tym większe, że niektóre źródła informują iż w czasie pandemii legalna sprzedaż papierosów w Polsce, w porównaniu z poprzednim rokiem, wzrosła o $6,8 \%{ }^{61}$. Stać się tak mogło ze względu na utrudnione kupowanie papierosów od imigrantów zza wschodniej granicy. W sytuacji, gdy grupa palących tytoń Polaków sięga 8 milionów osób, gdy każdego dnia - z powodu palenia tytoniu - przedwcześnie umiera ponad tysiąc osób, gdy $60 \%$ deklaruje chęć rzucenia palenia, należy uznać, że potrzeba przeciwdziałania temu uzależnieniu jest koniecznością. Udzielanie pomocy do zerwania z nałogiem, podjęcie prewencji, profilaktyki i terapii oraz wychowania do odpowiedzialności za zdrowie i życie człowieka nadal pozostaje wyzwaniem naszych czasów.

\section{ZAKOŃCZENIE}

Pozytywne tendencje współczesnej psychoprofilaktyki - według Zbigniewa Gasia - są ukierunkowane nie tylko na grupy ryzyka, ale na wszystkie lokalne społeczności; nie koncentrują się na negatywnych, lecz na pozytywnych stronach życia, nie poprzestają na redukowaniu, ani nawet eliminacji czynników ryzyka, ale wzmacniają ludzkie atuty; zamiast działań, będących jedynie reakcją na dostrzegane problemy, podejmują wspieranie wartościowych możliwości, zamiast selektywnych i wąskozakresowych problemów przyjmują programy uniwersalne dotyczące całego społeczeństwa ${ }^{62}$.

Powodem sukcesu profilaktyki palenia tytoniu byli ludzie przekonani do słuszności przedsięwzięcia, pogłębiający wiedzę o szkodliwości używek i wyrażający drugiemu człowiekowi miłość, która nie szkodzi. To ludzie zaangażowani i pracowici, gotowi chronić innych przed złem i oddani dobru, ludzie, których pasja pociągnęła rzesze, od kilkusettysięcznych miast wojewódzkich po maleńkie miasta i wsie. Przyczyną sukcesu jest działalność

\footnotetext{
60 Tamże.

${ }^{61}$ Polska wyróżnia się w Europie. Dzięki palaczom, 7.02 .2020 (dostęp 10.06.2021), https:// www.money.pl/gospodarka/polska-wyroznia-sie-w-europie-dzieki-palaczom-6475994727016577a.html

62 Zbigniew Bronisław Gaś, „Redukcja szkód a profilaktyka uzależnień”, Remedium 7-8 (2002): 32-33.
} 
w różnych ośrodkach, organizacjach i instytucjach, wykorzystanie istniejących struktur w służbie zdrowia i oświacie, a także tworzenie nowych fundacji, stowarzyszeń i koalicji. Sukces powiązany jest ze wzajemnym wsparciem i współpracą (także zagraniczną), oddziaływaniem na decydentów, korzystaniem z gotowości szerzenia, przydatnej w profilaktyce, wiedzy przez przekonanych o słuszności sprawy dziennikarzy. Istotnym dla stwierdzonych osiagnięć było zaangażowanie badawcze, pozyskiwanie, opracowywanie i publikowanie wyników uzasadniających przedstawiane postulaty. Czynnikiem sukcesu była różnorodność form działań: warsztaty, szkolenia, nagrody, kampanie, akcje, a nade wszystko konferencje kontynuujące dzieło Profesora Franciszka Venuleta. Podstawą sukcesu była też psychoprofilaktyka integralna: angażująca świat polityki i Kościoła, życzliwie przyjmująca osoby chętne do współpracy i szanujące człowieka traktowanego jako ucieleśnionego ducha i uduchowione ciało.

Dotychczasowe sukcesy, podobnie jak i niepowodzenia, w profilaktyce patologii społecznej powinny przyczyniać się do wyciagania właściwych wniosków i podejmowania działań służących zdrowiu człowieka i rozwojowi ludzkiej społeczności. Osobowe wzorce wybitnych profilaktyków mogą stanowić dodatkowa motywację działań dla ich naśladowców i kontynuatorów dzieła.

\section{BIBLIOGRAFIA}

Blanke, Douglas, Vera de Costa e Silva. Tools for advancing tobacco control in the 21st century. Tobacco Control Legislation: An introductory guide. Geneva: World Health Organization, 2004.

Cekiera, Czesław. Etiologia i motywacja usiłowanych samobójstw. Studium psychologiczne. Warszawa: Akademia Teologii Katolickiej, 1975.

Cekiera, Czesław. Papierosy. Palacy problem palenia. Toruń: Europejskie Centrum Edukacyjne, 2013.

Cekiera, Czesław. Psychoprofilaktyka uzależnień oraz terapia i resocjalizacja osób uzależnionych. Metody, programy, modele, zakłady, wspólnoty. Lublin: Towarzystwo Naukowe Katolickiego Uniwersytetu Lubelskiego, 1992.

Cekiera, Czesław. Ryzyko uzależnień. Lublin: Towarzystwo Naukowe Katolickiego Uniwersytetu Lubelskiego, 1994.

Cekiera, Czesław. Toksykomania: narkomania, lekomania, alkoholizm, nikotynizm. Warszawa: Państwowe Wydawnictwo Naukowe, 1985.

Cekiera, Czesław. Tytoń. Lublin: Wydawnictwo KUL, Wydawnictwo „Gaudium”, 2005.

Cekiera, Czesław. W obronie życia $i$ zdrowia. Białystok: Wydawnictwo Niepaństwowej Wyższej Szkoły Pedagogicznej, 2011. 
Cekiera, Czesław, Witold Zatoński (red.). Palenie tytoniu wolność czy zniewolenie? Lublin: Towarzystwo Naukowe Katolickiego Uniwersytetu Lubelskiego, 2001.

Centrum Badania Opinii Społecznej. Palenie papierosów. Komunikat z badań, Nr 104/2019: 2, https://cbos.pl/SPISKOM.POL/2019/K_104_19.PDF. Dostęp 07-07-2021.

Czalej-Hurko, Anna. „Korelaty osobowości a uzależnienie od tytoniu w wybranych grupach młodzieży", w Palenie tytoniu wolność czy zniewolenie? red. Czesław Cekiera, Witold Zatoński, 53-58. Lublin: Towarzystwo Naukowe Katolickiego Uniwersytetu Lubelskiego, 2001.

Czapiński, Janusz, Tomasz Panek (red.). Diagnoza Społeczna 2013. Warunki i jakość życia Polaków. Raport, 265-268. Warszawa: Ministerstwo Pracy i Polityki Społecznej, Centrum Zasobów Ludzkich, 2014.

Danysz, Andrzej. „Prof. Franciszek Venulet - pionier polskich badań nad wpływem dymu tytoniowego na stan zdrowia". Alkoholizm i Narkomania 36(1999), 3: 325-332.

Drewnowska, Beata. „Obrazkowe ostrzeżenia na papierosach w Polsce”. 10.10.2011. Dostęp 10.06.2021, https://www.rp.pl/artykul/730642-Obrazkowe-ostrzezenia-na-papierosach-wPolsce.html

Dudziak, Urszula. „Dziecko zagrożone dymem tytoniowym”, w Międzynarodowy Kongres „O godność dziecka. Warszawa 18-20 maja 2001, red. Ewa Kowalewska, Małgorzata Wyszyńska, 129-139. Gdańsk: Klub Przyjaciół Ludzkiego Życia, 2001.

Dudziak, Urszula. Na nowej drodze życia bez papierosa. Materiaty dla doradców życia rodzinnego. Poznań: Fundacja „Glos dla Życia”, 2002.

Dudziak, Urszula. Na nowej drodze życia bez papierosa. Poznań: Fundacja „Glos dla Życia”, 2002.

Dudziak, Urszula. Nauczyciel a profilaktyka palenia tytoniu - Przewodnik. Warszawa: Fundacja „Promocja Zdrowia”, 2006.

Dziewiecki, Marek. Profilaktyka integralna. Kraków: Rubikon, 2007.

Fetlińska, Janina, „Problemy zwalczania palenia tytoniu w Polsce: sprawozdanie z dziesięciu Ogólnopolskich Konferencji Naukowych im. Prof. Franciszka Venuleta (lata 1998-2007)". „Medycyna Nowożytna” 15(2008), 1-2: 188-197.

Fundacja „Promocja Zdrowia”. Dostęp 07.06.2021, http://promocjazdrowia.pl/dzialania-fundacji/

Fundacja „Promocja Zdrowia”. Dziatania Fundacji. Dostęp 07.06.2021. http://promocjazdrowia. $\mathrm{pl} / \mathrm{dzialania-fundacji/}$

Fundacja „Promocja Zdrowia”. Nagrody Fundacji. Dostęp 09.06.2021, https://promocjazdrowia. $\mathrm{pl} /$ nagrody-fundacji/

Fundacja „Promocja Zdrowia”. O Fundacji. Nasze działania. Dostęp 10.06.2021, https://promo cjazdrowia.pl/nasze-dzialania/

Fundacja „Promocja Zdrowia”. Journal of Health Inequalities. Dostęp 09.06.2021, https://pro mocjazdrowia.pl/jhi-2/

Fundacja „Promocja Zdrowia”. Misja i cele. Dostęp 09.06.2021, https://promocjazdrowia.pl/ misja-i-cele/

Fundacja „Promocja Zdrowia”. Żaden zysk nie może być zasadny, jeśli kosztem jest życie ludzkie. Zakaz sprzedaży papierosów w Watykanie, 10 czerwca 2021. Dostęp 10.06.2021, https://promocjazdrowia.pl/zakaz-sprzedazy-papierosow-w-watykanie/

Gałązka-Bazydło, Teresa. „Poziom neurotyzmu u toksykomanów, alkoholików i palaczy”. W Palenie tytoniu wolność czy zniewolenie? red. Czesław Cekiera, Witold Zatoński, 101117. Lublin: Towarzystwo Naukowe Katolickiego Uniwersytetu Lubelskiego, 2001.

Gaś, Zbigniew Bronisław. „Redukcja szkód a profilaktyka uzależnień”. Remedium 7-8 (2002): 32-33. 
Główny Inspektorat Sanitarny. Sprawozdanie z realizacji Programu ograniczania zdrowotnych następstw palenia tytoniu w Polsce w 2015 roku. Warszawa: Rada Ministrów, 2016.

Grzelak, Szymon. „Czwarte ogniwo profilaktyki”. Remedium 7-8(2001): 8.

Grzelak, Szymon. Profilaktyka ryzykownych zachowań seksualnych. Kraków: Rubikon, 2009.

Hajek, Peter, Anna Phillips-Waller, Dunja Przulj, Francesca Pesola, Katie Myers Smith, Natalie Bisal, Jinshuo Li, Steve Parrott, Peter Sasieni, Lynne Dawkins, Louise Ross, Maciej Goniewicz, i in. „A Randomized Trial of E-Cigarettes versus Nicotine-Replacement Therapy”. New England Journal of Medicine 380(2019):629-637. DOI: 10.1056/NEJMoa 1808779. Dostęp 04.06.2021.

Hintz, Iga. Jak rzucić palenie? Jak działaja plastry, gumy, spraye, pastylki na rzucanie palenia? 31 maja 2019. Dostęp 04.06.2021, https://apteline.pl/artykuly/jak-rzucic-palenie-jakdzialaja-plastry-gumy-spraye-pastylki-na-rzucenia-palenia.

Horszko-Szmyd, Barbara. „Poczucie zmian w obrazie siebie u osób z uzależnieniem nikotynowym, w Palenie tytoniu wolność czy zniewolenie? red. Czesław Cekiera, Witold Zatoński, 119-136. Lublin: Towarzystwo Naukowe Katolickiego Uniwersytetu Lubelskiego, 2001.

Jaworski, Janusz Marek, Dorota Linke-Drzyżdżyk, Krzysztof Przewoźniak i Witold Zatoński. „Profilaktyka chorób odtytoniowych - narodowe kampanie zdrowotne”. W Palenie tytoniu w Polsce: postawy, nastęstwa zdrowotne i profilaktyka, red. Witold Zatoński, Krzysztof Przewoźniak, 281-294. Warszawa: Centrum Onkologii - Instytut, 1999.

Jaworski, Janusz Marek, Krzysztof Przewoźniak, Witold Zatoński. „15. lecie kampanii zdrowotnej «Rzuć palenie razem z nami» sukcesy i wyzwania”. W IX Ogólnopolska Konferencja Naukowa im. prof. Franciszka Venuleta „Tytoń albo Zdrowie” Ptock 07-08 listopada 2006. Materiaty konferencyjne. Płock: Centrum Psychologiczno-Pastoralne Metanoja, 2006.

Kontrola i promocja zakazu palenia tytoniu prowadzona przez Państwowa Inspekcje Sanitarna. Warszawa: Główny Inspektorat Sanitarny, 2012.

Lalik, Agnieszka. „Poczucie zmian obrazu siebie u palącej papierosy młodzieży szkoły średniej”. W Palenie tytoniu wolność czy zniewolenie? red. Czesław Cekiera, Witold Zatoński, 137-174. Lublin: Towarzystwo Naukowe Katolickiego Uniwersytetu Lubelskiego, 2001.

Lalik, Agnieszka. „Profilaktyka palenia papierosów przez młodzież szkoły średniej”. W Palenie tytoniu wolność czy zniewolenie? red. Czesław Cekiera, Witold Zatoński, 227-252. Lublin: Towarzystwo Naukowe Katolickiego Uniwersytetu Lubelskiego, 2001.

Michalewski, Bartosz. Centrum drop in w Krakowie. Ograniczanie szkód zdrowotnych i praca $z$ użytkownikami narkotyków $w$ dobie pandemii COVID-19. Opublikowano: 28 stycznia 2021. Dostęp 04.06.2021, https://www.narkomania.org.pl/czytelnia/ograniczanie-szkod-zdro wotnych-i-praca-z-uzytkownikami-narkotykow-w-dobie-pandemii-covid-19/.

Miech, Olga. „Niektóre cechy osobowości palaczy i abstynentów nikotynowych”, opr. Urszula Dudziak. W Palenie tytoniu wolność czy zniewolenie? red. Czesław Cekiera, Witold Zatoński, 59-71. Lublin: Towarzystwo Naukowe Katolickiego Uniwersytetu Lubelskiego, 2001.

Misiuna, Małgorzata. „Obywatelska Koalicja «Tytoń albo Zdrowie»”. W X Ogólnopolska Konferencja Naukowa im. prof. Franciszka Venuleta „Tyton albo Zdrowie”. Ptock 07-08 listopada 2006”. Materiały konferencyjne. Płock: Centrum Psychologiczno-Pastoralne Metanoja, 2006.

Ostrzeżenia zdrowotne na opakowaniach wyrobów tytoniowych. Art. 9b. Ustawy o ochronie zdrowia przed następstwami używania tytoniu i wyrobów tytoniowych. Dz. U.2021 poz. 276 Wersja obowiązująca od: 11 lutego 2021 r.

Palenie tytoniu i Ty. Składniki dymu tytoniowego. Dostęp 10.06.2021, http://palenie.doktorzy. $\mathrm{pl} / \mathrm{dym} . \mathrm{htm}$.

Polska wyróżnia się w Europie. Dzięki palaczom, 7.02.2020. Dostęp 10.06.2021, https://www. money.pl/gospodarka/polska-wyroznia-sie-w-europie-dzieki-palaczom-6475994727016577a.html 
Program Ograniczania Zdrowotnych Następstw Palenia Tytoniu w Polsce. Cele i zadania na lata 2014-2018, opr. Minister Zdrowia. Warszawa: Rada Ministrów, 2013.

Przewoźniak, Krzysztof, Witold Zatoński. „Zakaz reklamy tytoniu w Polsce i jego wpływ na postawy młodzieży wobec palenia tytoniu". W IX Ogólnopolska Konferencja Naukowa im. prof. Franciszka Venuleta „Tytoń albo Zdrowie”. Płock 07-08 listopada 2006. Płock: Centrum Psychologiczno-Pastoralne Matanoja w Płocku 2006.

Przewoźniak, Krzysztof. „Rzuć palenie razem z nami” - kampania zdrowotna dla rzucajacych palenie - Zdrowie w ciaży - uzależnienia od alkoholu, tytoniu i narkotyków, 2 maja 2017. Dostęp 10.06.2021, https://www.zdrowiewciazy.pl/uzaleznienia-w-ciazy/uzaleznienie-od-ty toniu/369-rzuc-palenie-razem-z-nami-kampania-zdrowotna-dla-rzucajacych-palenie.

Przewoźniak, Krzysztof, Jakub Gumkowski, Małgorzata Zagroda, Paweł Polak, Sylwia Kolakowska, Barbara Witeska, Daniel Pokrywczyński, Janina Fetlińska i Witold Zatoński. „Zanieczyszczenie miejsc publicznych w Polsce dymem tytoniowym”. W IX Ogólnopolska Konferencja Naukowa im. prof. Franciszka Venuleta „Tytoń albo Zdrowie” Płock 07-08 listopada 2006. Materiaty konferencyjne. Płock: Centrum Psychologiczno-Pastoralne Metanoja, 2006.

Rzeszowska, Katarzyna. „Obraz siebie u palaczy i inhalantomanów”. W Palenie tytoniu wolność czy zniewolenie, red. Czesław Cekiera, Witold Zatoński, 175-195. Lublin: Towarzystwo Naukowe Katolickiego Uniwersytetu Lubelskiego, 2001.

Starek, Andrzej. „Toksykologia dymu tytoniowego”. W Zdrowotne następstwa palenia tytoniu w Polsce, red. Witold Zatoński, Krzysztof Przewoźniak, 61-73. Warszawa: Ariel, 1992.

Ustawa z dnia 9 listopada 1995 r. o ochronie zdrowia przed następstwami używania tytoniu i wyrobów tytoniowych (Dz. U. 1996, Nr 10, poz. 55); Data wejścia w życie 1 maja 2016; Wejście w życie ostatniej zmiany 11 lutego 2021, Dz. U. 2021, poz. 276.

Venulet, Franciszek. Co o nałogu palenia tytoniu wiedzieć należy. Warszawa: „Wiedza Powszechna", 1956

Wojcieszek, Krzysztof. „Mity i zasady profilaktyki uzależnień”. Remedium 5(2002): 16-18.

Wojtasiński, Zbigniew. WHO: liczba palacych papierosy mężczyzn przestaje rosnac $i$ zacznie spadać (20.12.2019). Ministerstwo Edukacji Narodowej, Nauka w Polsce. https://naukawpo lsce.pap.pl/aktualnosci/news\%2C80018\%2Cwho-liczba-palacych-papierosy-mezczyzn-przesta je-rosnac-i-zacznie-spadac. Dostęp 07.07.2021.

Wojtyła, Karol. Promieniowanie ojcostwa. Wrocław: Wydawnictwo Wrocławskiej Księgarni Archidiecezjalnej TUM, 2007.

Zatoński, Mateusz. „Marking the 20th anniversary of the Polish Anti-Tobacco Law”. Journal of Health Inequqlities 2(2016).

Zatoński, Witold. Apel z okazji Światowego Dnia Rzucania Palenia. Dostęp 10.06.2021, https:// promocjazdrowia.pl/apel-fundacji-promocja-zdrowia-z-okazji-swiatowego-dnia-rzucania-pale nia/\#_ftnref1

Zatoński, Witold, Krzysztof Przewoźniak. „Zawartość substancji smolistych sprzedawanych w Polsce w latach 1983-2000". Zdrowie Publiczne i Zarzadzanie 7(2009), 2: 12-19.

Zatoński, Witold. Demokracja jest zdrowsza: cud zdrowotny nad Wista. Warszawa: Centrum Onkologii - Instytut, 2004.

Zatoński, Witold, Urszula Sulkowska i Joanna Didkowska. „Kilka uwag o epidemiologii nowotworów w Polsce". Nowotwory Journal of Oncology 65(2015), 3: 179-196.

Zatoński, Witold (red.). Europejski Kodeks Walki z Rakiem. Wydanie polskie na podstawie European code against cancer and scientific justification: third version. Warszawa: Centrum Onkologii - Instytut im. Marii Skłodowskiej-Curie, 2003. 
PRZYCZYNY SUKCESU

W POLSKIEJ PROFILAKTYCE PALENIA TYTONIU

\author{
S t r e s z c z e n i e
}

Odnotowany w połowie drugiej dekady XXI wieku spadek ilości sprzedawanych papierosów w Polsce, zmniejszenie się liczby palaczy oraz mniejsza liczba zachorowań na raka płuc wśród mężczyzn od 35 do 54 roku życia skłaniają do podjęcia pogłębionej refleksji nad tym, dzięki czemu udało się to osiągnąć. Celem analiz, podjętych w niniejszym artykule, było wyodrębnienie przyczyn osiągniętego sukcesu oraz prezentacja polskiego świadectwa zaangażowanej pracy profilaktycznej, zarówno w krajowych, jak i międzynarodowych kręgach. Warto to uczynić dla: odnotowania historii dokonań, docenienia twórców sukcesu, pozyskania naśladowców, ukazania cennego przykładu kontynuatorom działań prozdrowotnych. Materiał zgromadzony w przedstawionym tekście pozyskano dzięki: udziałowi w licznych Konferencjach im. prof. Franciszka Venuleta dotyczących profilaktyki palenia tytoniu; poświęconym temu zagadnieniu publikacjom oraz osobistej znajomości konkretnych działań podejmowanych bądź inspirowanych przez prof. dr. hab. Witolda Zatońskiego i ks. prof. dr. hab. Czesława Cekierę, a także ich współpracowników z Instytutu - Centrum Onkologii im. Marii Curie-Skodowskiej w Warszawie, Fundacji „Promocja Zdrowia” i Katedry Psychoprofilaktyki Społecznej Katolickiego Uniwersytetu Lubelskiego.

Słowa kluczowe: palenie tytoniu; psychoprofilaktyka; sukces w Polsce. 